назад? / Євген Пасічник // Українська література в школі. - 2002. - № 3. - С. 46-50. 7. Пасічник Є. Ясла повні (?) / Є. Пасічник, О. Слоньовська // Українська мова та література. - 2002. - № 22. - С. 17-21. 8. Пасічник Є. Міністр пропонує школярам малювати горщечки? // Дзеркало тижня. - № 24. - 2005. [Електронний ресурс] / Євген Пасічник. - Режим доступу: http://gazeta.dt.ua/EDUCATION/ministr_proponue_ shkolyaram.html

УДК 371.134:811

Ольга Семенова

\title{
МЕТОД ПРОЕКТУВАННЯ ЯК ОДИН 3 АКТИВНИХ МЕТОДІВ ФОРМУВАННЯ ФУНКЦІОНАЛЬНОӤ КОМПЕТЕНТНОСТІ МАЙБУТНІХ УЧИТЕЛІВ ІНОЗЕМНОЇ МОВИ
}

Семенова О. О. Метод проектування як один 3 активних методів формування функціональної компетентності майбутніх учителів іноземної мови.

У статті розглянуто один 3 активних методів формування функціональної компетентності майбутніх учителів іноземної мови - метод проектування. 3'ясовано проблеми компетентнісного підходу у підготовці вчителів іноземної мови.

Ключові слова: метод проектування, компетентнісний підхід, функціональна компетентність, учитель іноземної мови.

Семенова О. А. Метод проектирования как один из активных методов формирования функциональной компетентности будущих учителей иностранного языка.

В статье рассматривается один из активных методов формирования функциональной компетентности будущих учителей иностранного языка - метод проектирования. Обоснованы проблемы компетентностного подхода в подготовке учителей иностранного языка.

Ключевые слова: метод проектирования, компетентностный подход, функциональная компетентность, учитель иностранного языка.

Semenova O. O. Projecting method as one of the active methods of forming the functional competence of future foreign language teachers.

The article describes one of the active methods of forming the functional competence of future foreign language teachers - the method of projects. The author substantiates the issues concerning the competency approach while training foreign language teachers.

Key words: projecting method, competenvy approach, functional competence, foreign language teacher.

Соціально-економічні зміни в суспільстві, реформування вищої педагогічної освіти на гуманістичних та демократичних засадах потребують підвищення рівня професійної підготовки майбутніх педагогів. Від педагога в сучасних умовах вимагається здатність до інноваційної діяльності, до самостійності та нестандартності рішень, функціональної компетентності.

Компетентнісний підхід в українському освітньому просторі нині відігріє роль універсальної методологічної парадигми: змінюються основи та принципи фахової підготовки спеціаліста, вища освіта трансформується зі «знаннєвоорієнтованої», якою вона була ще із часів появи перших європейських університетів, на сучасну, «практико-орієнтовану». Компетентність педагога виявляється у трьох типових діях: 
діяти автономно і рефлексивно, використовувати різноманітні дидактичні засоби для вирішення професійних проблем і функціонувати в колективі [3]. У цьому плані особливу практичну значущість набуває функціональна компетентність як важливий показник рівня сформованості його професіоналізму. Зростаючий інтерес до компетентнісного підходу в підготовці сучасного вчителя іноземної мови можна пояснити назрілими змінами до постановки мети, принципів відбору змісту й оцінювання освітніх результатів вищої педагогічної освіти. Функціональну компетентність розглядаємо як здатність майбутнього спеціаліста до пізнавальної та практичної діяльності для оптимального розв'язання педагогічних проблем i виконання професійних функцій.

Формування функціональної компетентності студентів у процесі вивчення предметів гуманітарного циклу неможливе без реалізації компетентнісного підходу до організації навчального процесу та дотримання сукупності педагогічних умов, що забезпечують його результативне здійснення. Компетентнісний підхід до організації пізнавальної діяльності студентів 3 вивчення іноземної мови реалізується за допомогою активних форм та методів. На думку науковців (О. Антонов, В. Бухбіндер, А. Вербицький, Л. Рожин, О. Садікова, Е. Скалкін), активні форми й методи роботи найбільш повно відображають специфіку процесуальної сторони навчання та позитивно впливають на формування компетенцій, які є показниками функціональної компетентності. Одним із методів $є$ метод проектування.

Mema cmammi: обгрунтувати метод проектування як один 3 активних методів формування функціональної компетентності майбутніх учителів іноземної мови.

Гуманітарне знання у проектній технології $\epsilon$ не стільки метою, скільки інструментом спілкування, засобом залучення студентів до активного пізнавального процесу. У науковій літературі під навчальним проектом розуміють спеціально організований викладачем i самостійно виконаний студентом комплекс дій, спрямованих на розв'язання практично значущої проблеми (А. Король, С. Кукліна, $\begin{array}{lll}\text { I. Кукуленко-Луб'янець, } & \text { К. Лінгвістоун, } & \text { Р. Щербаков). }\end{array}$ проблематика, яка передбачає комплексне використання знань, роботу у групі [2]. Завдання мають нестандартний, пошуковий характер. Наведемо приклади завдань:

Here is the letter student should write if he is interested in attending classes at Greenwich School.

Complete the letter using the words and phrases below.

a) would like; b) first of all; c) also; d) sincerely; e) have been studying; f) I am writing; g) look forward to.

Dear Ms March, in order to apply for one of the scholarships you are offering for summer course at the Greenwich School of English. I am seventeen years old and (2) English for five years. I passed my First Certificate in June 1997. I have the Cambridge Proficiency. My just started a course leading to mother tongue is French, but also I know some German.

I (3) to say why I think I should be awarded one of the scholarships. (4) English is one of my favorite subjects and I have been getting good marks at school. I feel that now I need to practice what I have learnt in real situation. I would (5)__ like to know more about British life and culture. I am very interested in literature and read a lot of English books and magazines. My favorite English author is Agatha Christie and I have always wanted to see places where her stories are set.

I enclose a letter to reference from my English teacher. I hope you will give my application careful consideration. 
I (6) hearing from you,

Yours (7)

Навчальні проекти з філологічних проблем у вивченні гуманітарних дисциплін стимулюють розвиток професійних, мовних і комунікативних компетентностей. Студенти вдосконалюють здібності (навчаються на основі раніше засвоєної інформації структурувати нові знання, формулювати проблему, прогнозувати шляхи та способи ії розв'язання, чітко висловлювати власну точку зору, чітко викладати аргументи на iї захист, виявляти винахідливість, оригінальність, гнучкість i нестандартність мислення, ініціативу і самостійність). Під час виконання навчальних проектів удосконалюється функціональна компетентність, зокрема іiі змістовий та організаторський компоненти (уміння працювати 3 різними джерелами інформації, викладати та представляти результати, планувати, організовувати процес роботи, розподіляти час, прогнозувати результати та власні навчальні досягнення).

Робота над проектом передбачає поетапний характер і поєднує різні види діяльності:

- формування позитивної мотивації;

- вибір теми проекту (колективне обговорення, суперечка, пропозиції та побажання);

- добір інформаційного матеріалу (постановка запитань, непряма мова);

- робота студентів у групах;

- збір інформації за допомогою анкетування, методу інтерв'ю;

- наочне представлення інформації (складання графіків, діаграм, схем);

- презентація проекту.

Студенти для виконання проекту об'єднуються в групи (по 3-5 осіб), але не більше 5 осіб. Група отримує завдання, де розписані, терміни та форма подання проміжних результатів. Розподіл ролей у команді, способи розв'язання поставлених завдань визначаються студентами самостійно. Підсумковий результат повинен бути представлений у письмовому вигляді, повідомлений на публічному захисті.

Ураховуючи те, що студенти неповною мірою готові до роботи над проектом та недостатньо компетентні в питаннях, пов'язаних із розв'язанням проблеми, ставляться завдання, виконання яких розширює теоретичні, методологічні, професійні знання й уміння студентів, удосконалює їхні процесуальні дії.

Під час роботи над проектом студенти вивчають спеціальну літературу, опановують методику виконання практичних дій. Розв'язання поставленого завдання забезпечує не тільки набуття знань та умінь, необхідних для виконання проекту, але й поповнює багаж професійних знань, розвиває організаторські здібності, відпрацьовується організаторський компонент функціональної компетентності майбутніх викладачів іноземної мови.

Як уже зазначалося, робота над проектом має поетапний характер. На підготовчому етапі обирається тема проекту, проводиться ознайомлення з лексичним матеріалом і складається план проекту. Студенти ознайомлюються 3 довідковою літературою, уточнюють понятійний апарат, проводять його інтерпретацію, здійснюють через Інтернет пошук необхідної літератури. Акцент робиться на формуванні лінгвістичних знань, набутих під час ознайомлювання 3 лексикограматичним або літературним матеріалом за темою проекту, актуалізації мовних i комунікативних навичок, необхідних задля забезпечення мовної діяльності, придбанні проектних, інтелектуальних умінь. На цьому етапі увага акцентується на розвитку психологічного компонента функціональної компетентності, стимулюється позитивна 
мотивація.

У процесі спільного планування студентами проекту вдосконалюються комунікативні уміння, розвиваються організаторські здібності під час постановки проблеми, розв'язання проблемних ситуацій, формуються інтелектуальні уміння, пов'язані з пошуком необхідної інформації та роботою з літературою, що є основою розвитку креативно-процесуального, комунікативно-рефлексивного компонентів функціональної компетентності студентів.

Основний етап роботи над проектом становить самостійна робота студентів. Кожне заняття планується як ланка єдиного цілого, яке охоплює собою вивчення теми iз застосуванням проектної технології. На другому етапі реалізовуються основні елементи методичної системи навчання студентів гуманітарного знання та практичних умінь, які є показниками функціональної компетентності.

На завершальному етапі проекту відбувається його презентація, обговорення досягнутих результатів та оцінювання. Під час обговорення аналізуються дії студентів, спрямовані на розв'язання практичних завдань, використання ними мовних засобів i комунікативних навичок. Для оцінювання отриманих результатів використовуються різні параметри. Так, реферати оцінюються 3 позиції розвитку письмових навичок студентів; монологічне мовлення, яке використовується в основному під час презентації проекту, оцінюється за якісними характеристиками й кількісними показниками монологічних висловлювань студентів. До уваги беруться також такі показники, як: оригінальність, своєрідність презентації; інформативність, використання різних джерел інформації; професійна спрямованість запропонованих рішень проекту; естетичне його оформлення, наочність, дотримання часових меж. Усе це слугує підставою для розвитку аналітико-оцінювального компонента функціональної компетентності студентів.

Для участі у проектній діяльності необхідні знання з гуманітарних дисциплін, добре володіння засвоєним матеріалом, навичками комунікації, організаторськими уміннями. Робота над проектом у невеликих групах сприяє розвитку комунікативних здібностей, співпраці та співтворчості, веденню дискусій, узгоджених дій, спрямованих на досягнення поставлених цілей.

Робота в команді вимагає певних особистісних якостей: уміння поважати чужу думку, пристосовуватися один до одного, оцінювати власні досягнення та помилки. Студентам на проміжних етапах звітності оцінка за виконання завдань не ставиться, надається можливість вільно висловлювати критичні зауваження. Це стимулює роботу над проектом, допомагає сформулювати висновки та врахувати їх у майбутній професійній діяльності [1].

МАТРИЦЯ ПРОЕКТУ за темою: «Свята та традиції Великобританії».

Предмет: англійська мова

Курс: 1

Мета проекту:

- створити умови для практичного використання навичок усного мовлення в англійській мові;

- формувати уміння працювати в групах, використовуючи метод співпраці;

- сприяти розвитку пізнавальних інтересів до культури та звичаїв країни, мова якої вивчається.

Завдання проекту:

- розвиток уміння працювати з текстом та виокремлювати головну інформацію;

- розвиток навичок аудіювання, діалогічного мовлення; 
- розвиток уміння імпровізації прослуханого тексту.

Тип проекту: рольовий, практико-орієнтований, творчий.

Характер проекту: міжпредметний.

Розділи науки: країнознавство, англійська мова, інформатика.

Обладнання: комп'ютер, проектор, реквізити до імпровізації, слайди, тексти, ілюстрації, картки для оцінювання, папір, олівці, фломастери.

Очікуваний результат: імпровізація англійських традицій та свят. Створення альбому з короткою інформацією про ці свята.

Час роботи: 1 пара.

За кількістю учасників: груповий, парний.

Важливим моментом у проектній діяльності $є$ рефлексія, тобто аргументована оцінка власної діяльності й діяльності своїх партнерів, що закріплює уміння аналізу своїх і чужих дій та їх наслідків, успіху чи неуспіху, їх причини, прогнозувати висновки щодо майбутніх дій.

Використання методу проектів дає змогу студентам проявити творчість i активність, нестандартно мислити та діяти, приймати рішення і відповідати за свої дії окрім того, така робота позитивно впливає та розвиває змістовий, організаторський, психологічний, креативно-процесуальний, комунікативно-рефлексивний та аналітикооцінювальний компоненти, які $\epsilon$ показниками функціональної компетентності майбутніх учителів іноземної мови.

\section{Література}

1. Белякова М. А. Международная проектная деятельность как способ раскрытия творческого потенциала личности ученика / М. А. Белякова // Иностранные языки в школе. - 2007. - № 3. - С. 79-82. 3. Голуб Г. Б. Метод проектов как технология формирования ключевых компетентностей учащихся/ Г. Б. Голуб, О. В. Чуракова. - Самара, 2003. - 315 с. 3. Родигіна І. В. Компетентісно орієнтований підхід до навчання / Ірина Володимирівна Родигіна. - Х. : Основа, 2006. - 96 с.

Тетяна Стас

\section{ПЕДАГОГГЧНІ УМОВИ ФОРМУВАННЯ ЕМОЦІЙНОЇ КУЛЬТУРИ МАЙБУТНІХ УЧИТЕЛІВ ПОЧАТКОВОЇ ШКОЛИ ЗАСОБАМИ ОБРАЗОТВОРЧОГО МИСТЕЦТВА}

Стас Т. В. Педагогічні умови формування емоційної культури майбутніх учителів початкової школи засобами образотворчого мистецтва.

У статті схарактеризовано педагогічні умови формування емоційної культури майбутніх учителів початкової школи засобами образотворчого мистецтва: забезпечення емоційно-вольової регуляції змісту навчальної діяльності; застосування творчих проектів як складника емоційного відгуку; застосування системи навчальних i творчих завдань, інтерактивних методів і прийомів, активних форм організації практичної діяльності студентів на заняттях з образотворчого мистецтва; посилення емоційного аспекту у викладанні дисциплін образотворчого мистецтва.

Ключові слова: педагогічні умови, майбутній вчитель початкової школи, емпатія, проект, проектування, інтерактивні методи.

Стас Т. В. Педагогические условия формирования эмоциональной культуры будущих учителей начальной школы средствами изобразительного искусства.

В статье определены педагогические условия формирования эмоциональной 